\title{
Apocalypse in Islam, by Jean-Pierre Filiu
}

\author{
Berkeley and Los Angeles: University of California Press, \\ 20II | 288 pages | ISBN: 978-0-5202-643I-I (hardcover) \\ $\$ 47.95$
}

Jean-Pierre Filiu's Apocalypse in Islam is an innovative and meticulous work, able to meet the expecta-

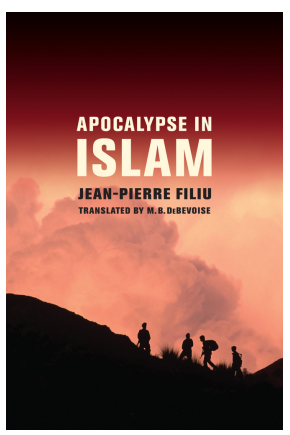
tions of scholars of Islamic eschatology. This book is a translation of L'Apocalypse en Islam published in 2008 and would indeed be more comprehensible if read along with additional supplementary works by Bernard Lewis, Michael Cook, and David Cook. The manifestation of several avatars, who have claimed to be, and introduced themselves as enders of time or masters of time (sahib al-zaman), exhibits the significance of apocalypse for human beings. Islamic texts have frequently employed different terms for the end of time, or akhir al-zaman, such as yawm al-qiyamah, yam al-hashr, yawm al-hisab, yawm al-din, etc., which imply the existence of a [divine] court and justice at the end. Apart from Islamic texts, many Muslims and non-Muslims have disclosed events and features of the final days of this world (dunya). In the theological-eschatological context, this type of prediction is called "apocalypse." As Filiu explains, the emergence of the notion of apocalypse in Islam dates back to the pre-prophecy period of Muhammad, when Bahira—a Christian hermit—foresaw that Muhammad would become a Prophet. Hence, the first part of the book ("True and False Messiahs of Islam"), opens with special reference to archeology and a background of the end of the world in Islam. The author aptly links cosmological-Qur'anic notes with certain specific events and calamities to indicate Islamic predictions regarding the final days of this world. Among examples of the Qur'anic apocalypse prophecy are splitting of the moon (inshaqq al-qamar) in Q 5 I:I3, the sky's transformation into smoke (dukhan) in Q 44:I0, and the mountains' dissolution in Q 70:9 in the last moments of life on earth. Nevertheless, these predictions cannot provide specific calendar dates concerning the final days of the world. Likewise, Filiu stated that "Rich though it is in descriptions of the Final Judgment and of hell and heaven, the Qur' an provides few clues regarding the apocalyptic calendar" (6). Filiu expanded his idea that Islamic traditions (i.e., Muhammad and his companions' statements, so-called hadiths) explore Islamic apocalypse more profoundly. Thus, for Filiu, "The 
great schism" is the starting point which signifies that the death of Muhammad was the main basis behind schismatism among the prophetic ummah.

The death of Muhammad, struck down by a sudden illness in 632, plunged the young Muslim community into disarray. He left no political testament, no instructions to his followers regarding the collective management of the faith after his death (6). Similarly, several scholars have previously stated that the

death of the Prophet precipitated a severe religious and political struggle within the Islamic community, which developed into bitter internecine conflict, eventually splitting the umma into two antagonistic sects: "the people of the Sunna" and the Shi'a.

It would however, have been more useful if the author had more strongly stated that many Shi'a believers remain confident that Muhammad left an important political testament and elected 'Ali as his successor in Ghadir Khum on I 8 Dhu'l-Hijjah (March Io, 632).

When Muhammad was returning from his Farewell Pilgrimage he stopped at Ghadir Khum ... to make an announcement to the pilgrims who accompanied him from Mecca and who were to disperse from this junction. By the orders of the Prophet, a special dais or pulpit made of branches of the trees was erected for him. After the noon prayer the Prophet sat on the pulpit and made his last public address to the largest gathering before his death three months later. Taking 'Ali by the hand, Muhammad asked his followers whether he was superior in authority and person (awla) to the believers themselves. The crowd cried out in one voice: "It is so, O Apostle of God." He then declared: "He of whom I am the mawla [the patron, master, leader, friend], of him 'Ali is also the mawla (man kuntu mawlahu fa 'Ali-un mawlahu). O God, be the friend of him who is his friend, and be the enemy of him who is his enemy (Allahumma wali man walahu wa 'adi man adahu)."

Moreover, the preceding detail regarding 'Ali ibn Abi Talib's status (as a mawla) following the Prophet's death could be linked by Filiu to the functions of the Umayyad heads (particularly after the 'Uthman's assassination), who were honored by two prophetic statements about the final moments of this world (Hour: $s a$ ' $a$ h): "at the end of My community there will be a caliph who will spend money without counting" (9), and "The Hour will not come until a man from Qahtan appears and drives the people with his stick" (9).

Through a historical analysis, Filiu considers two core hadith collections in Sunnism compiled by two Persian traditionalists (muhaddithun), Muham- 
mad ibn Isma'il al-Bukhari (809-70) and Abu al-Husayn Muslim bin alHajjaj al-Qushayri al-Nisaburi (c. 8 I 6-75). Astoundingly, Sahih al-Bukhari highlights a number of prophetic predictions which reveal that after Muhammad there would be conflicts, deviations and battles among the people of his ummah: "When I am no longer here, do not go back to idolatry, and do not kill each other," and "I see dissension falling among your dwellings as does the rain." Gradually the details of akhir al-zaman are associated to the emergence of a dissension (fitnah) and disappearance of knowledge and wisdom. Hereby, Islamic traditions examine further aspects of the final days. Dajjal, or Antichrist (plural: dajjalun: false Messiahs and charlatans), will come someday, and he will have a divine claim that he is al-Masih (Messiah). According to al-Bukhari and al-Muslim, the physical profile of dajjal, his followers, his location, and so on, are fully outlined. Subsequently, Filiu discusses the Shi'a doctrine of the Final Day and explains that it is based on Shaykh al-Mufid's al-Irshad and Shaykh at-Tusi's Tahdhib al-Ahkam.

Chapter 2 entitled "Grand Masters of the Medieval Apocalypse" evaluates the different views of five great Muslim scholars. Ibn 'Arabi (I I65I 240), the author of al-futuhat al-makkiyah, is the first person who "accepts the classical traditions concerning the appearance of the Mahdi in the sacred enclosure of Mecca, which, he adds, the people of Kufa will celebrate with a very special joy. Mahdi will be followed by seventy thousand Muslims, all descended from Isaac" (32). Al-Qurtubi (d. I273/67I) is the second scholar mentioned, who assembled al-tadhkirah $f$ ahwal al-mawta wa umur al-akhirah in which he cited al-Bukhari and al-Muslim. His main contention about the enders of this world is that al-Mahdi will appear in Morocco and pass the first ten years of his return preaching there. (37) Isma'il Ibn Kathir ( 30 I-73) claimed that Jesus will come down to the white minaret on the east side of Damascus and will kill the Antichrist. Jesus, for Ibn Kathir, would be a righteous leader. Later on, Filiu presents a rational image of Ibn Khaldun (1332-1406) and his view towards the Islamic apocalypse. Ibn Khaldun referred to the Sahihayn of Bukhari and Muslims:

The Muslims will follow him and he will subject all the lands of Islam to his authority. He will be called the Mahdi. After him will appear the Antichrist, as well as all the signs of the Hour, as these are laid down in the al-Sahih [of Bukhari and of Muslim]. Next, Jesus will come down to earth and kill the Antichrist. Or Jesus will come down with the Mahdi, help him to kill the Antichrist and take [the Mahdi] as Imam in his prayers (42). 
The final figure is Jalal al-Din al-Suyuti (I 446-1 505), who supported Ibn Hanbal's traditions by stating that "the Antichrist will stay on earth as long as Allah wishes it. Then Jesus, son of Mary, will come from the west, attesting the veracity of Muhammad and of his religion, and he will slay the Antichrist" (46). Hereby, Filiu displays various apocalyptical notes of Medieval Muslim thinkers who were directly or indirectly influenced by Sunni-Islamic hadith.

"Avatars of the Mahdi" comprises the third chapter of this book. It discusses individuals who introduced themselves as al-Mahdi. I truly enjoyed the way Filiu began by focusing on another crucial schism, i.e., the emergence of Isma'ilism. Although I expected Filiu to discuss other Shi' ite sects (e.g., Zaydiyah) more profoundly along with their views towards the ender and owner of times, he presented the diversity of the Mabdism doctrine in Shi'a thought quite nicely.

Likewise, he imparted how Muhammad, the son of Isma'il, who was the son of the sixth Imam of Shi'a, was ascribed to the Mahdi. Other examples of the Mahdi's Avatars in Shi' ism later on are Shaykh Fazlallah al-Astar Abadi (1339-94), notable for his virtues and the attempts of Antichrist at killing him, Nurbaksh, a Mahdi of Tajikistan, and Muhammad ibn Falah's (I 400$65 / 66)$, contending as friends of Mahdi in Iraq.

Part 2, with special reference to the modern apocalypse, begins with a contemporary, Islamic-political event that occurred in the dawn of the fifteenth century of Islam. This important event was the Islamic revolution of Iran led by Ayatullah Khomayni in I 979 CE. Filiu undoubtedly included this chapter in his book since the Islamic revolution in Iran was accompanied by wilayah al-faqih, or the authority of jurisprudence, who (i.e., a jurist) can be referred to as God's representative on earth. Therefore, there is a direct connection with the Mahdi and his occultation.

It is certain that the September I I, 200 I disaster conducted by Islamic extremist parties as well as the United States' invasion of Muslim countries based on the motto "global war against terror" facilitated the conception of novel apocalyptic literature. The new apocalyptic literature, by harnessing the rhetoric and images of both Muslim and Christian traditions, is able to distort and redirect sacred prophecy for its own purposes, and, with the invasion of Iraq, to reach a new and larger audience while at the same time strengthening the plausibility of its forecasts (I2O).

"The Grand Return of the Shi'i Mahdi," "Diasporas of the Apocalypse" and the "Armageddon of Jihad" are the remaining chapters, which connect religious-political elements to religious-futuristic desires of Muslims communities. 
In the end, Filiu provides readers with a valuable bibliography of apocalyptic works written by Muslim scholars. It would have been preferable if he had included supplementary apocalyptic works by Malay and Persian scholars.

Majid Daneshgar

University of Otago 